\title{
INVESTIGATING THE ARCHITECTURAL ORIGIN OF THE GAYEBI MOSQUE IN OSMANPUR, SYLHET, BANGLADESH
}

| Received August 23 ${ }^{\text {th }}, 2019$ | Accepted December 16 th, 2019 | Available online December 20 ${ }^{\text {th }}, 2019$

DOI http://dx. doi. org/10.18860/jia.v5i4.7569

\section{Shubhajit Chowdury}

Department. of Architecture

Shahjalal University of Science dan Technology (SUST)

Sylhet, Bangladesh

arshubhajit81@gmail.com

\section{Kawshik Saha}

Department. of Architecture

Shahjalal University of Science dan Technology [SUST]

Sylhet, Bangladesh

Kawshik.saha@gmail.com

\section{Mohammad Samsul Arefin}

Department. of Architecture

Shahjalal University of Science dan Technology [SUST]

Sylhet, Bangladesh

msanarch@gmail.com

Mahinul Haque

Architect, Sylhet, Bangladesh

Mahinul.haque@gmail.com

\begin{abstract}
This study aimed to investigate the architectural origin, style, and legacy of the Gayebi Masjid (Divine Mosque), which is located as a witness of time in Osmanpur, Balaganj, Sylhet, Bangladesh. The origin of the mosque is shrouded in mystery, as the actual construction period and the patronizing builder is unknown to the people. On the other hand, based on the characteristics and features, it can be generally assumed that the mosque was constructed either in the Sultanate or the Mughal period of Muslim rule in Bengal. The mosque has prominent architectural features that can also be found in other Sultanate and Mughal mosques in the surrounding region. However, the realtime period of construction of the mosque remains uncertain, as no other evidence, document, or argumentation can be found except the existing mosque's architectural features. For this study, the attributions and characteristics will be critically examined to form a comparative analysis to determine the mosque's origin and architectural style. The method of this research was a critical review and descriptive analysis of all the collected information, and the interpretation of some physical evidence from the field survey, as well as comparative analysis of the data with some other case studies. However, through this research and careful investigation, we conclude that the most convincing assumption is the original structure of the mosque resembles the architecture of the Sultanate period. On the contrast, more than a few additional architectural features were added during the later Mughal period.
\end{abstract}

\section{KEYWORDS:}

Investigating: Sultani architecture; Mughal architecture; Gayebi mosque Sylhet

\section{INTRODUCTION}

Sylhet, a north-eastern region of Bangladesh, is also known as "The Land of 360 Saints", highlighting its history and heritage as one of the core centers of Islam in Bengal [1]. Among all the architectural heritage buildings, such as mosques and shrines that can be found in the Greater Sylhet region, Gayebi Masjid (Divine Mosque) is one of the most significant ones.

It is located right next to the Balaganj- Osmaninanagar, the highway at Osmanpur village in the Balaganj sub-district of the Sylhet district. The location is around $6 \mathrm{~km}$ away from Tajour and $8 \mathrm{~km}$ away from Balaganj town. The mosque is surrounded by the typical natural rural context of Bangladesh from all sides, such as paddy fields in south and east. The main road at the north and a secondary village road on the west side can be found surrounding the complex. Some rural settlements of village elites are also located right next to the main road and the secondary road.
The exact origin and construction period of the mosque remain unknown, and quite mysterious today. Several legends and folktales are famous in the local community in regards to the source of the mosque. It is said that the Divine Mosque was uncovered from underneath of a hillock (locally known as 'tila'); and the actual builder and the construction period is unknown to the people who supposedly uncovered the architecture, as there is no inscription found. The mosque is not mentioned in any account, and it is impossible to date it precisely. But archaeologists suggest the mosque's construction period might be between the $15^{\text {th }}$ to $16^{\text {th }}$ centuries [2].

The local community still uses the Gayebi mosque for daily and Friday prayers; it is a landmark in the surrounding area. The design of the mosque contrasts with the local vernacular architecture, as the architectural features and materials of the mosque somewhat resemble other mosques of Bengal constructed during Islamic rule. 
The Gayebi Mosque has a domed roof, is made of bricks, and has columns and arches that are heavily influenced by Islamic architecture of the Indian subcontinent. Four corner turrets with floral cupola and floral cornice are also found in the mosque. In recent times, the mosque has been renovated several times to accommodate more people. These contemporary extensions and interventions can be easily traced, in contrast with the original structure of the mosque.

It is also believed that the mosque served an important role in the spreading of Islam in the surrounding region during the Muslim rule; its architecture is one of the most prominent heritage monuments in the area.

Given the significance and the lack of any information regarding its origin, the author decided to research to investigate and determine the architectural origin of the mosque. According to the present condition and architectural features, it can be assumed that the mosque was constructed either in the Sultanate or the Mughal period. On the other hand, it is difficult to provide a certain conclusion because the many features of the mosque can be found in both Sultanate and Mughal architecture, as should be found in the study.

Therefore, this study aimed to investigate and determine the true identity and origin of the architecture of the Gayebi mosque to ensure the survival of its legacy. We focused on critically examining the architectural features; then comparing them to the characteristics of some other known examples of Sultanate and Mughal mosques. Each of the points will be discussed in detail in this paper, and at the same time, logical arguments will be provided, along with as much as possible reference data. Obstacles in this study were that no such authentic historical documents, texts or sources were found, and the available information was minimal. So, to write this paper, the author had to rely on referenced sources in the form of books or articles, and most importantly, our data and findings collected from the physical survey and examination of the mosque.

However, this preliminary investigation is expected to give an idea about the most likely and most convenient architectural origin of the Gayebi mosque (Figure 1).

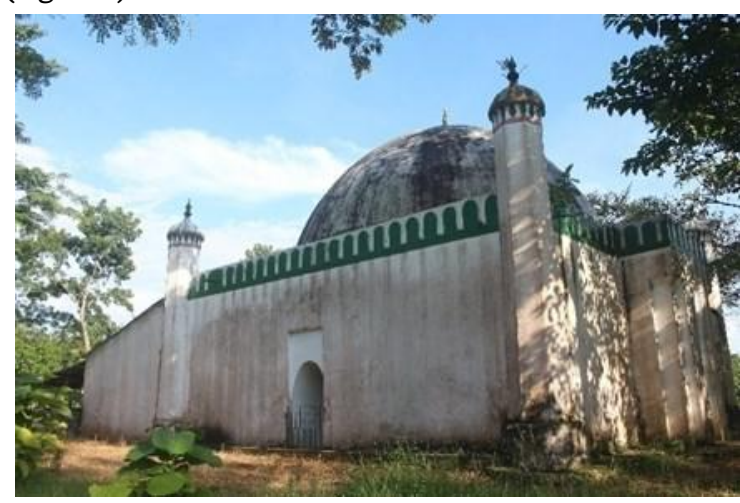

Figure 1. Gayebi mosque, source-author

\section{METHODS}

For this research, data and information were collected based on 1) literature, internet, books, articles, papers, and old documents related to the history of the Islamic rule in the Greater Sylhet region as well as Bengal, 2) A field survey, examining the present existing condition and the architectural features and characteristics of the mosque searching for evidence and taking photographs, and 3) an interview with the mosque's imam and local people. For lack of written documents or photography about the Gayebi mosque history, the author had to depend on local hearsay to understand the context and phases of changes with time. The questions were designed to get information about the chronology of the development of the mosque and the perception of style by local people.

The method of analysis was a critical review and descriptive analysis of all the collected information and interpretation of some physical evidence from the field survey; to understand its context and surroundings; and also comparative analysis of the data with some other case studies. The research was done by going over all the possibilities and looking for proof or logical arguments to determine the most rational conclusion.

For graphical documentation, direct measurement tools and topographical survey techniques were applied. Tools like Canon DSLR camera, laser distance meter, and digital theodolite were used for the survey. We used simple Photogrammetry techniques to prepare the initial drawings. AUTOCAD software was used for detail survey data processing. For $3 \mathrm{~d}$ modeling, we used Google Sketch Up software for documentation models.

\section{DISCUSSION}

\section{A BRIEF OVERVIEW OF MOSQUE ARCHITECTURE IN BENGAL}

The Mosque is a space for the Muslim people to worship God and recite a prayer. The English word 'Mosque' derives from the Arabic word 'Masjid' (a home for Allah) by the use of 'sajada' (a sacred place of prostration before Allah to sacrifice divine worship). It is a place for congregational prayers calling from the tall tapering minarets, a symbol of Muslim brotherhood, fraternal unity and solidarity throughout the global Muslim community. To understand the context of our research, we shall first have a brief discussion about the mosque architecture in Bengal, which includes both Sultanate and Mughal architecture.

The Muslim architecture has been initiated from the very beginning of Islamic heritage, which is started by the mosque, introduced by Prophet Muhammad (PBUH). By the gradual expansion of Islam, mosque architecture has been introduced in the Indian subcon- 
tinent via Persia at the very beginning of the $13^{\text {th }}$ century [3].

The Mosque architecture of 'Islam' in the Bengal was oriented identically from the Sultanate period by the $14^{\text {th }}, 15^{\text {th }}$ and $16^{\text {th }}$ century [4]. In this era, the Bengal mosque was prominently inspired and designed with single domical/multiple domical roofs, rich ornamental 'mihrab,' and 'mimbar,' the local vernacular architectural style like curved Chala roof, corner turrets and floral curving, and no minaret [5]. The clay brick and terracotta were the most widely used materials at that time as available. The style is widely scattered across the region. One of the most prominent examples of Sultanate architecture, the Sixty Dome Mosque (Shat Gambuj Masjid) of Bagerhat, is now a UNESCO World Heritage Site [6].

After the sultanate period, the Mughal architecture in Bengal, an inspiration of Islamic, Persian and Indian architecture, is developed by the Mughal in the 16th and 17th century and mostly iconic with forts, gardens, caravanserais, hammams, and fountains. The mosque, at that time, also developed a distinct provincial style with more sophisticated features such as the effective amalgamation of ideas, even symmetrically and decoratively materials. A three-sided multifold arched entrance doorway, multi-domical crown roofed prayer space, larger central dome and entrance doorway, less ornamentation with floral motifs, curvilinear cornice, accentuated turrets and corner turrets, plaster panel are the key features of Mughal mosque in this region. The Sat Gambuj Masjid (Seven Dome Mosque) of Dhaka near the Jafarbad area is an excellent example of the provincial Mughal architecture in the $17^{\text {th }}$ century [7].

The mosques in Bengal in Sultanate and Mughal period range from small to very large in scale. It is also ranging from mostly little low to plain high plinth. The main characteristics are multi-arched openings, less ornamentation with large decorated panels stand out in high relief against plain walls, curve projected cornice, curvilinear roof with single-dome, multi-dome, barrel vault, cross vault and amalgamation of these three types, symmetrical rectangular and square plan, and symmetrical rectangular facade. Plan includes an unusual square, nine-domed kind. Sometimes they have gateway entrance to the courtyard of main mosque structure, mostly single volumetric internal space, and sometimes verandah and inner chamber separated by 'maqsura.' Sometimes they also have enclosed patio, local clay brick masonry wall with veneer plaster or thin layer of limewash, and sometimes quarried stone column from temple supports the massive roof, circular corner massive turrets with pinnacle niches, very few in numbers have high 'minaret' connected by a verandah with the main chamber, less decoration, single or/and multi 'mihrab,' step up 'mimber,' floral and terracotta motifs to the internal frontier facade and massive appearance represents the traditional Bengal architectural style and show considerable influence from Tughluq architecture of Delhi.

To understand and make a comparative analysis, we shall present a few prominent case studies from both the Sultanate and Mughal era to comprehend their architectural features and characteristics.

\section{CASE STUDY OF SULTANATE ARCHITECTURE IN BENGAL}

\section{The Chunakhola mosque}

The Chunakhola mosque is a single domed mosque, locally considered to be contemporary with Khan Jahan Ali style mosques of present-day Bagerhat, Bangladesh. Based on architectural style, the date of construction can be estimated to be the mid-fifteenth century (Figure 2) [8].

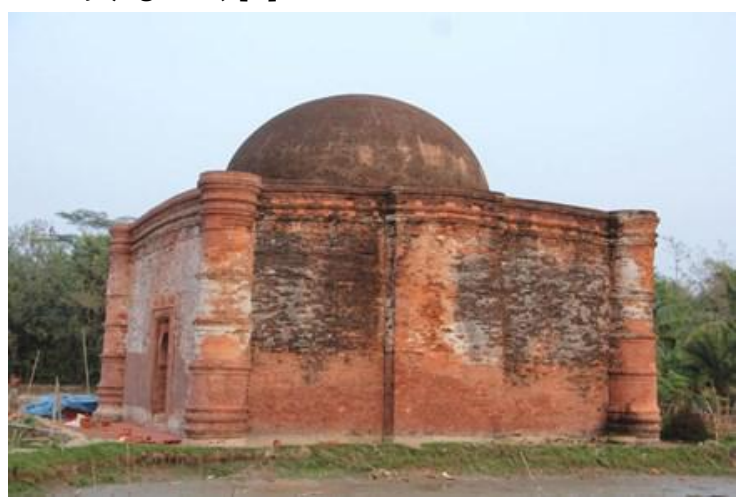

Figure 2. Chunakhola mosque. [8]

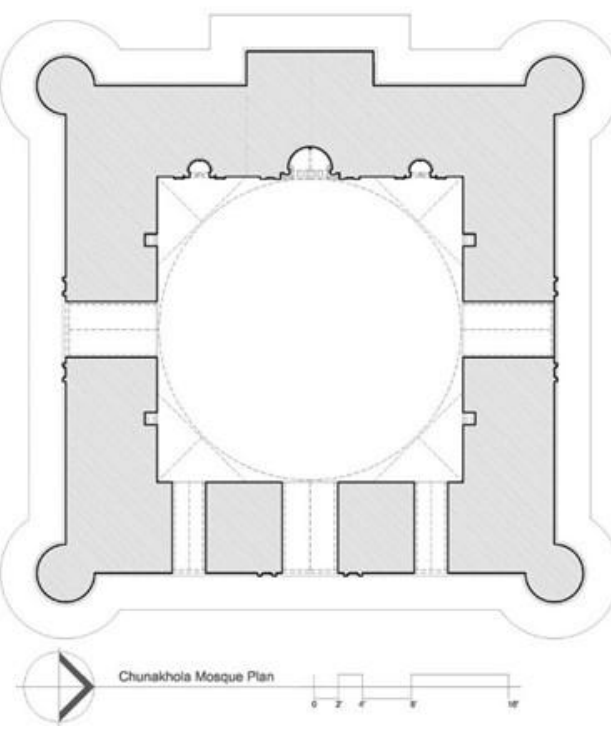

Figure 3. Chunakhola Mosque plan. [8]

Figure 3 shows that the structure is a single square chamber, roofed over by a single hemispherical dome. The eastern façade has three arched openings to the prayer hall, where northern and southern façades have one arched opening each. The dome is internally carried on by four intersecting arches springing from stone pillars and brick pilasters attached to the side walls. There are three mihrabs, each aligned with the three entrances at east, and the central portion of the qibla wall is projected westward from the ground to the roof. Four corner circular turrets buttress the square structure. These turrets end at the 
level of parapet walls and ribbed in typical Bengali Sultanate fashion. Curvilinear cornices of pre-Mughal type cap the façades. Exterior façades are of plain brick texture with advanced frame arched opening with terracotta jali designs. There are also three terracotta mihrabs in the qibla wall, which are flanked by small pillars with terracotta at the base and the capital [9] [10].

\section{Baba Adam Mosque}

Baba Adam Mosque, named after Baba Adam Shahid in Munshiganj, Bangladesh, is another example of the Sultanate period mosque, which was established in $1483 A D$ by Malik Kafur as a Jame mosque (figure 4) [6].

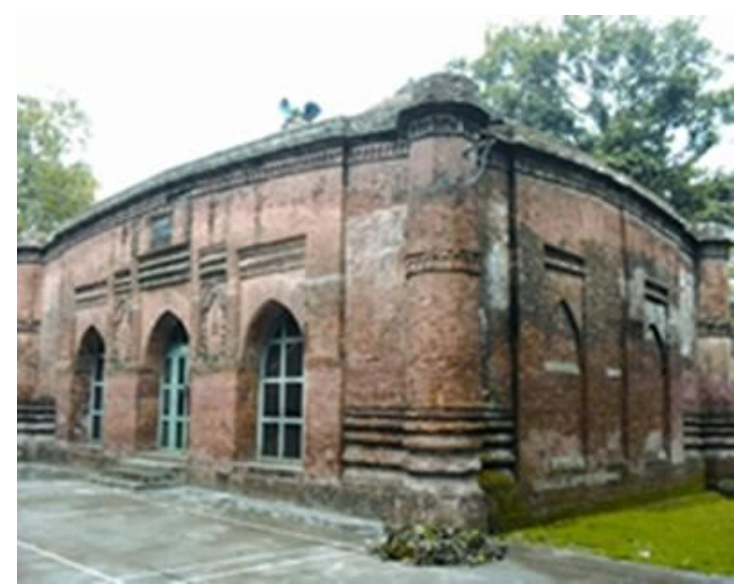

Figure 4. Baba Adam Mosque. [8]

It is a rectangular and hypostyle mosque with three bays and two aisles covered by six domes. The façade is less ornamented with large decorated panels stand out in high relief against plain walls. A thin layer of limewash, once probably painted, is sometimes still visible on the surface of the terracotta plaques. All the entrances and mihrabs are recessed within rectangular frames. The south and north walls contain rectangular niches. The mosque does not have a minaret. On both sides of the central doorway, there are two multicusped rectangular panels. The arches are supported on small faceted pillars and decorated with a beautiful terracotta floral design and a hanging motif. The grave of Saint Baba Adam Shahid stands nearby the mosque [7] [11].

\section{The Gopalgonj Mosque}

The Gopalgonj Mosque, another prominent Sultanate style mosque, is located in Dinajpur, Bangladesh, and was built around 1460 A.D. The prayer hall of the mosque is cubical and once had a single hemispherical dome over the roof, which no longer exists now. It is exceptional with its frontier verandah connecting the square prayer chamber and the additional external towers, just as in a residential hut. The western wall has three mihrabs, positioned opposite the three arched entrances. The terracotta decoration that fills the tympana of the mihrabs in the interior is remarkable for its liveliness and deep relief (figure 5).

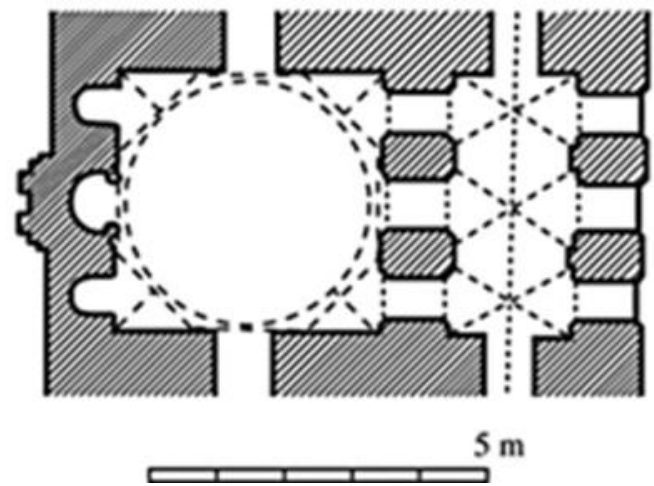

Figure 5. Gopalganj Mosque plan. [8]

\section{The Shat Gumbad Mosque}

The Shat Gumbad Mosque (Sixty Dome Mosque) (figure 6), located in Bagerhat, Bangladesh, is the largest and most significant mosque of Sultanate style architecture. It was constructed by Khan Jahan Ali, around 1442, and is now recognized as a UNESCO World Heritage site [12]. It has eleven bays and seven aisles, with the largest bay in the center. This central bay is divided into seven independent, rectangular bays that are covered by the chau'-chalas; this being the earliest use of the form in Bengal. It connects the largest entrance in the east to the largest mihrab and divides the mosque into northern and southern wings. The interiors of the miniature chau-chalas have thin, raised bands of brick that imitate the rafters and purlins of bamboo hut frames.

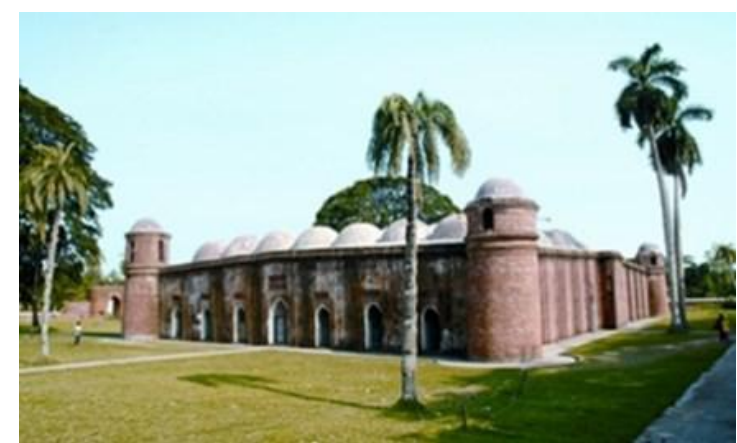

Figure 6. Shat Gumbad Mosque. [8]

The rest of the bays also terminate in mihrabs, except the one immediately north of the central mihrab, which has an entrance doorway reserved for the Imam, so that he can enter directly from behind the mosque. There are seven entrances, each on the north and south sides. It seems that the stone pillars once had brick casings on their bases. Recesses articulate the bare exterior walls. The curved cornice comes to a point over the central arched doorway in the east, resulting in a triangular-shaped pediment, which is probably derived from the gable ends of do-chala huts. 
The four circular tapering corner towers are domed, and the two in front have staircases inside. The monumental gateway in the east indicates that there was probably once an enclosing wall around the mosque.

\section{CASE STUDY OF MUGHAL ARCHITECTURE IN BENGAL}

In contrast to the buildings of the Sultanate period, which have a marked regional character, Mughal buildings are constructed within the imperial tradition of Delhi and Agra but are more subdued than contemporary architecture elsewhere in the subcontinent. As in Sultanate times, Mughal mosques consist of only a prayer hall, which is now single-aisled with three or five bays. The exterior surfaces are plastered and paneled, the cornices are straight, and the buildings look less ponderous than Sultanate ones because of the higher domes.

A refined Mughal provincial style was developed in the capital city of Dhaka in the 17th century. The Lalbagh Fort Mosque in Dhaka dated (1649 AD) and (1780 AD) conforms to the typical Mughal mosque plan (Figures 7 and 8) [15]. Located inside the fort, closest to the river, it was probably the earliest building on the site.

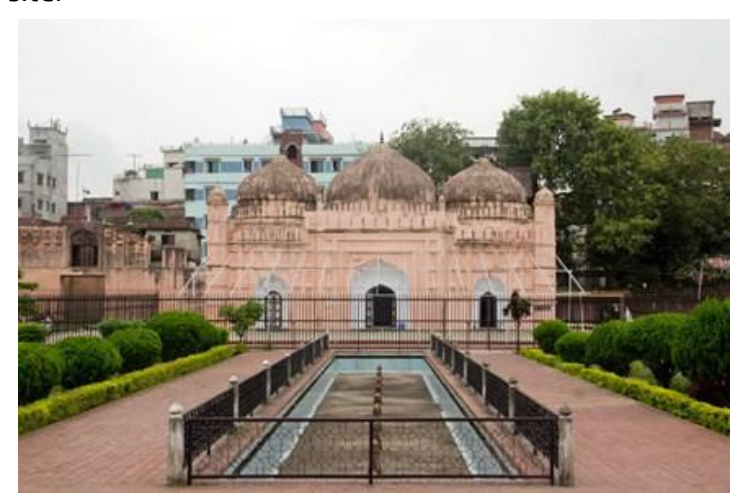

Figure 7. Lalbagh Fort Mosque. [8]

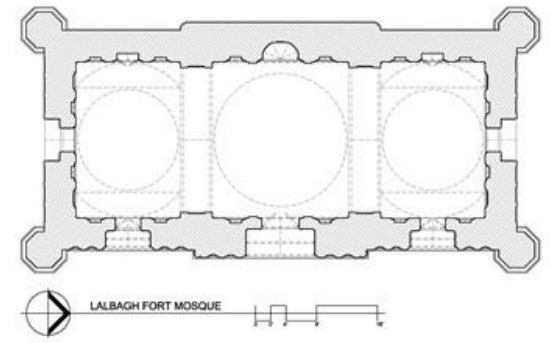

Figure 8. Plan of Lalbagh Fort Mosque. [8]

The mosque is a rectangular structure crowned with three-domes. It is one of the most excellent examples of its kind, where the central dome is larger [16]. Lateral arches in the interior divide the rectangular structure into three bays, the central one being the largest. The building is plastered, and the entire east facade is divided into small rectangular panels, the engaged tapering corner turrets have regularly spaced horizontal moldings. The three doors in front are placed within recessed arches with half-domes ornamented with faceted stucco motifs. The straight cornice is embellished with a row of merlons; its height varies, the central section, which corresponds to the largest bay, being the highest. Inside, the north and south walls have panels like the exterior, and the stucco motifs of the entrances are repeated in the three mihrabs.

\section{SUMMARY OF THE CASE STUDIES}

The summarize of the study on the essential characteristics of the two types of Islamic Architecture in Bengal can be seen in Table 1. There is a clear understanding of the distinct features and architectural aspects of some of the major mosques in Bengal from the Sultanate and Mughal period, which will enable us to form a co parative analysis of the architecture of Gayebi Mosque.

Table 1: Comparison between Sultanate and Mughal mosques

\begin{tabular}{lll}
\hline Features & Sultanate Architecture & Mughal Architecture \\
\hline Form & Simple form; generally square-shaped & $\begin{array}{l}\text { Larger than Sultanate mosques; generally rectangular- } \\
\text { shaped; imperial flavor }\end{array}$ \\
\hline Prayer space & Single square-shaped chamber & A rectangular or oblong shaped room or chambers \\
\hline Dome & $\begin{array}{l}\text { Single or multiple hemispherical domes; } \\
\text { domes }\end{array}$ & $\begin{array}{l}\text { Multiple domes; higher than Sultanate domes; in most } \\
\text { cases three domes: larger one at the center, two smaller } \\
\text { at each side }\end{array}$ \\
\hline Pinnacle & Not found & \begin{tabular}{l} 
Vertical pinnacle on domes \\
\hline Arch
\end{tabular} \\
$\begin{array}{lll}\text { Pointed or accurate arches; sometimes parabolic } \\
\text { arches; supporting the dome, also used as arched } \\
\text { entrance and windows }\end{array}$ & $\begin{array}{l}\text { Three-sided multifold pointed-arched entrance doorway; } \\
\text { and arched windows }\end{array}$ \\
\hline Turret & Octagonal corner turret & Corner turrets with regular spaced horizontal moldings \\
\hline Cupola & Not found & Floral cupola found on turret \\
\hline Cornice & Cantilever curved cornice & Straight cornice, with a row of Marlon \\
\hline Decoration & No excessive ornamentation & $\begin{array}{l}\text { Stucco motifs, panels, floral and geometric patterns used } \\
\text { as decoration }\end{array}$ \\
\hline Minaret & Not found & In most cases, minaret may be found \\
\hline
\end{tabular}




\section{AN INVESTIGATION OF GAYEBI MOSQUE}

As we have highlighted the basic information regarding the Gayebi Mosque (figure 9) in the Introduction section, now we shall discuss the mosque in detail by exploring its historical background, architectural features, and existing condition.

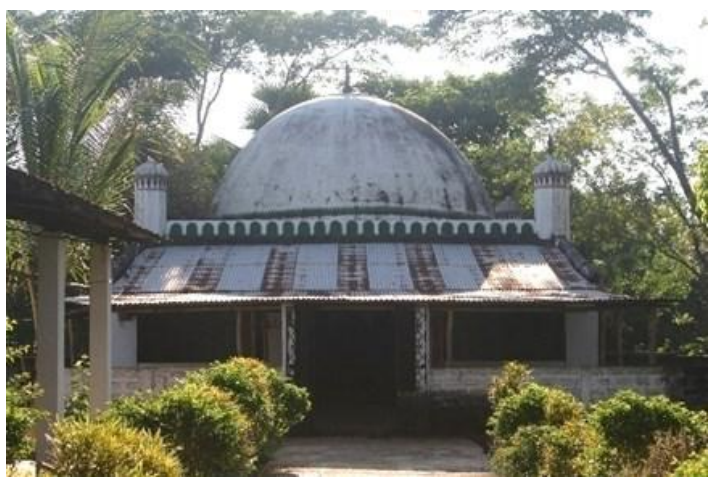

Figure 9. Front view of the Gayebi mosque. (photograph by Authors)

\section{HISTORICAL BACKGROUND}

The actual construction period and the patronizing builder of the mosque are unknown because the Muslim people uncovered it during the early period of the Islamic expedition in the Sylhet region contemporary to the great Muslim scholar Hazrat Shahjalal. In 1303 (703 Hidhri) during the reign of Sultan Firuz Shah of Delhi, one of his commander Sikandar Khan Gazi conquered Sylhet with the help of Hazrat Shahjalal and his Followers [13]. After establishing the central power in the Sylhet city by defeating the earlier ruler of the region, Gour Gobinda, the central administration aimed to achieve stability by setting up outposts for administrative purposes. The followers of Hazrat Shahjalal were appointed to those outposts for not the only administrative purpose but also to enlighten the local people under the light of Islam. At that time, mosques were frequently used for the administrative purpose in the newly conquered regions [14].

Osmanpur village was initially inhabited by Hindu people [14]. They claimed the people before Islam were Hindus of Purakayastha title. Still, controversially, local people mentioned a portion of the village was named Lamapara, which indicates a residential locality of Buddhist people [15]. Buddhist or Hindu or both groups of people lived either in a separate region or in juxtaposition in this village.

In this context, the hearsay states: when the provincial government of Sylhet region sent Syed Osman Bogdadi, a follower of Hazrat Shahjalal (R) with Syed Mahbub Khandakar and Syed Tahir Khandakar who were the sons of another follower Syed Omar Samar- kandi, they initially searched for an appropriate place to build a mosque. They found a hillock like a mound and chose their site for construction. When Bogdadi and his companions started to excavate the hillock like the mound to build a mosque, they discovered the existence of a permanent structure underneath the hillock. Then it was claimed by the local Hindu and Buddhist people as their temple, and Muslims also claimed it as a mosque. Then a treaty was made among them that, if it were proven as a mosque, the Hindu and Buddhist people would leave the village, and if it were proven otherwise, the Muslims would leave for good. Based on this treaty, all the people together started excavating the hillock and revealed the structure. After examining, based on some features of this structure like Entry from Eastside, it was agreed to be a mosque and named as the 'Gayebi Mosque' (The Divine Mosque). As per the treaty, the Hindus left the place and this place was renamed as "Osmanpur" after the name of Khawaja Osman Bogdadi (R) instead of its previous name 'Bhagabanpur.' However, the truth of the hearsay regarding the discovering of the mosque is disputed. It is more likely that the mosque was built by the local Muslim ruler for religious and administrative purposes during the earliest period of Islam in the region.

\section{THE ARCHITECTURAL FEATURES OF GAYBEI MOSQUE}

This research will show a comparative study of every prominent feature of this built form. Most of the information regarding the architecture of the mosque has been collected by a physical survey conducted on the site of the mosque. This study will help to determine the accurate construction period of this building as far as possible.

\section{Prayer hall}

The main prayer hall of this structure is square in the plan of 19 feet 3 inch each arm and surrounded by 61 inches thick wall. There are two windows at north and south and three arched doorways at the east. This simple organization of the prayer hall of the mosque is quite similar to the space of the single dome mosques or mausoleums built in Sultanate period in Bengal, such as Chunakhola mosque and Khan Jahan Ali's mausoleum at Bagerhatin South Bengal whose construction period can be dated back to 15 century A.D.

As a mosque, it is necessary to have the 'Mihrab' at the west wall. Indeed, there is a solid form attached to the west wall of the mosque which looks like 'Mihrab' from the outer side, and the convex space for Mihrab is seen in the interior. It proves that the main building and the Mihrab like structure at the outer surface are not built at the same time (figure 10, 11, 12). 


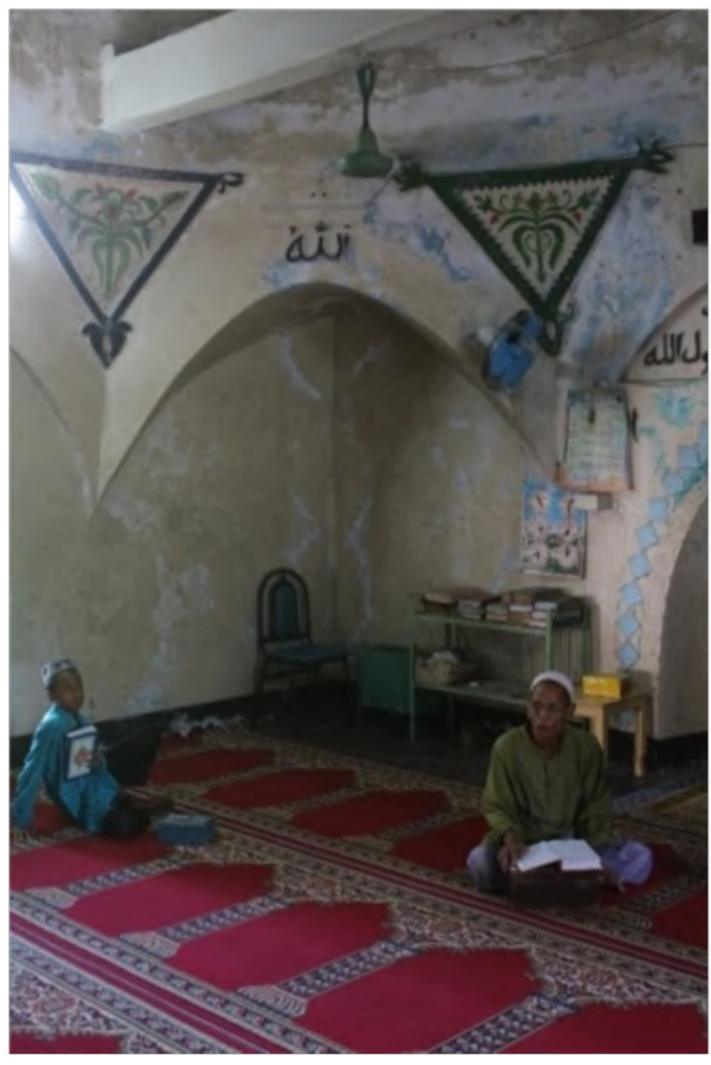

Figure 10. The Parabolic arch in the wall (photograph by Authors)
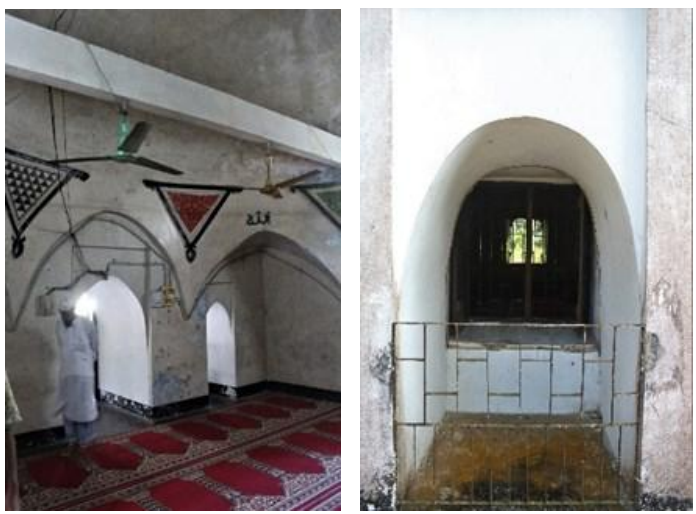

Figure 11. the parabolic arch as the window, (photograph by Authors)

\section{Pointed and Parabolic Arches}

Three pointed arches are seen on three entry doors in the east wall. In most of the Sultanate mosques, we can see pendentives to support the dome. But in this mosque, we did not find any defined pendentives. Instead, we found the use of parabolic arches to support the dome instead of a pendentive. There are eight parabolic arches; four to the corners and four from the wall made an octagonal base to support the dome. Some triangular decorations are used for structural purpose.

The parabolic arches are also seen on the side windows. This feature of the parabolic arc is somewhat unique, as the use of parabolic arches can be rarely found in Muslim architecture of the Indian subcontinent, somewhat true arches in the Sultanate period and pointed arches in the Mughal period were commonly used.

\section{The Dome}

The dome of this structure is an actual dome, which resembles most of the other mosques and mausoleums constructed in the Sultanate period (figure 13) [16]. The dome is approximately 10 feet high from the rooftop of the prayer hall. There is also a pinnacle on the top of the dome which is approximately 2 feet long from the top of the dome. It is notable that with some exceptions, such thing is rare in sultanate mosques. Though pinnacles were used in some Mughal architecture by observing the structural core, it can be assumed that the current pinnacle is added or replaced in the later Mughal period. Though we are not sure that if there was any pinnacle of the non-metallic core before this one built during the mosque's original construction.

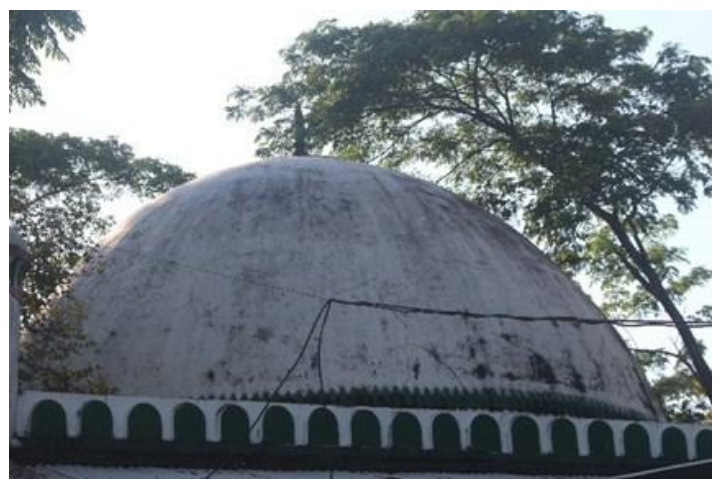

Figure-13: The dome, (photograph by Authors)

\section{Corner turrets:}

There are four octagonal corner turrets with floral cupola standing above the cylindrical base which is similar to the design style of Mughal architecture (figure 14). The approximate height of the turrets is 17 feet from the ground. Notably, we can see the use of octagonal corner turrets, which were commonly used in the Sultanate period, and also the use of cupola from the Mughal period of Mosque architecture. So, the context here is quite confusing as characteristics from two different periods exist in the same feature. So, we can assume that the octagonal corner turrets were built during the original construction, while the floral cupola was added during a later period.

\section{Floral Cornice}

Generally, we find curved cantilever cornice in Sultanate architecture. On the other hand, in the Gayebi mosque, we see straight cornice with Marlon, which is a feature of Mughal architecture. It is not sure if there were any curved cornice before but it can be 
said undoubtedly that it is not possible to have Marlon in the Sultanate of earlier architecture. So it is quite definite that the floral cornice was added to the original structure during a later period.

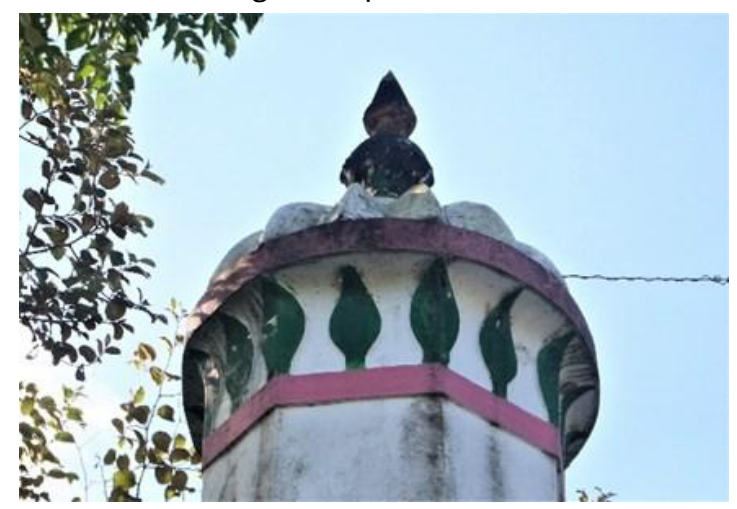

Figure 14. Corner turret \& cupola, (photograph by Authors)

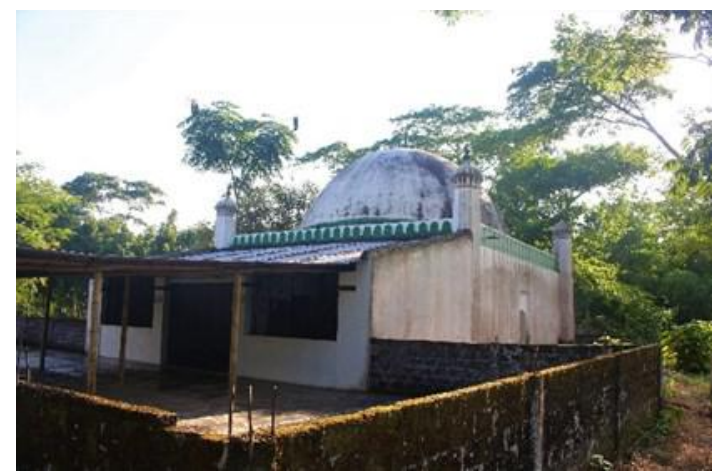

Figure 15. The front view, (photograph by Authors)

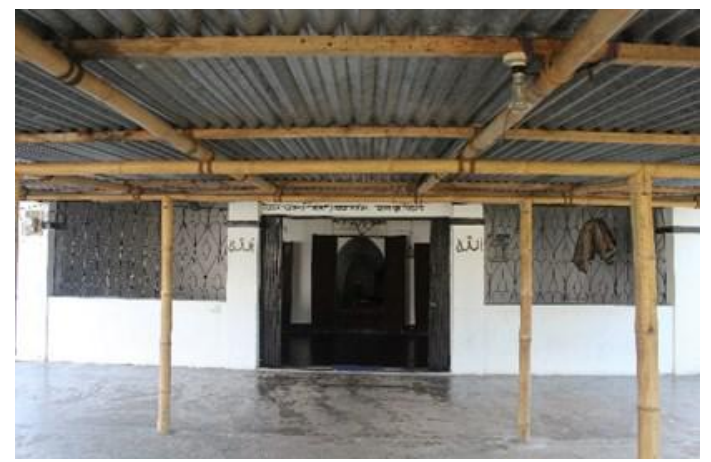

Figure 16. The extension, (photograph by Authors)

\section{EXISTING CONDITION:}

The number of Muslim people of this locality has been increased day by day, where only 53 people can be accommodated inside the mosque at a time. A corrugated iron sheet shaded extension, which was constructed during the Pakistan period (the 1950s), can accommodate additional 160 people, where the present requirement is to provide at least 300 people at a time on Jummah day Friday prayer. Currently, the extra people pray on the adjacent approach road during Jummah prayer.

After passing a long lifetime and due to large scale earthquakes, cracks are seen to the dome and other portions of the mosque, such as the exterior wall (figure $15 \& 16$ ). There is also evidence of various phases of repairing and restoration. As the repairmen held on later phases were done by using cement-mortar instead of lime- mortar, that's why they didn't mix up with each other appropriately. Moreover, the corrugated iron sheet shaded extension which was built to accommodate the increased amount of people, ruined the uniqueness of the original structure.

\section{ARCHITECTURAL DRAWINGS:}

As a part of this research, we have prepared architectural drawings of this historical mosque, such as plan, top view, elevation, and section from the data collected from our extensive survey, for future reference, as no documents were previously available (Figure 17-23).

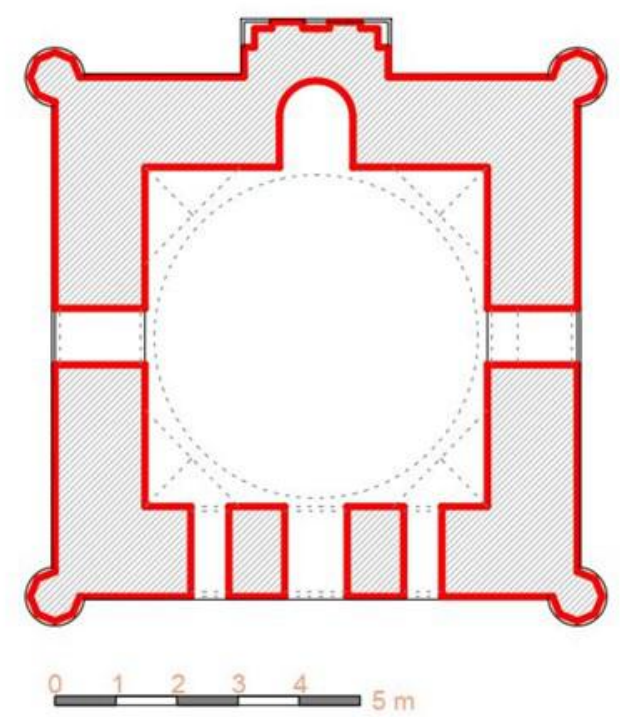

Figure-17: Plan of Gayebi mosque. (Drawn by authors)

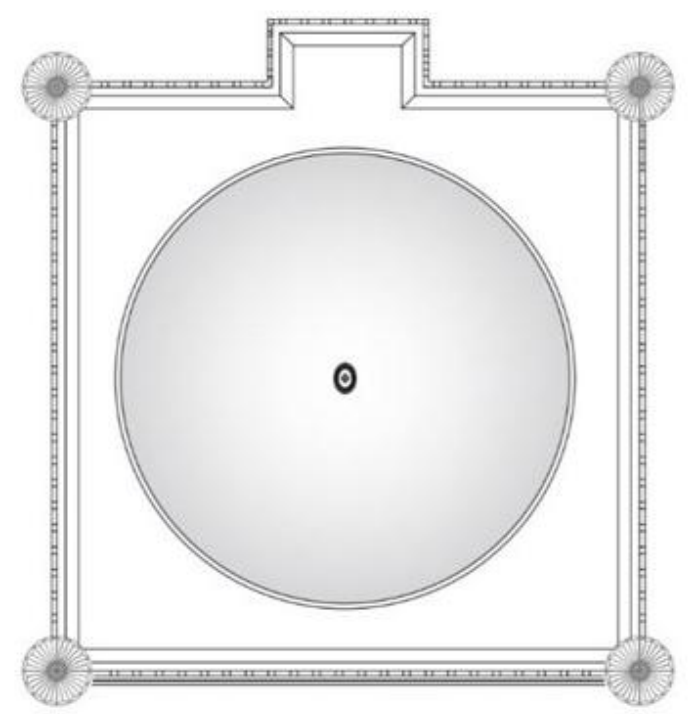

Figure 18: Top View of Gayebi mosque. (Drawn by authors 


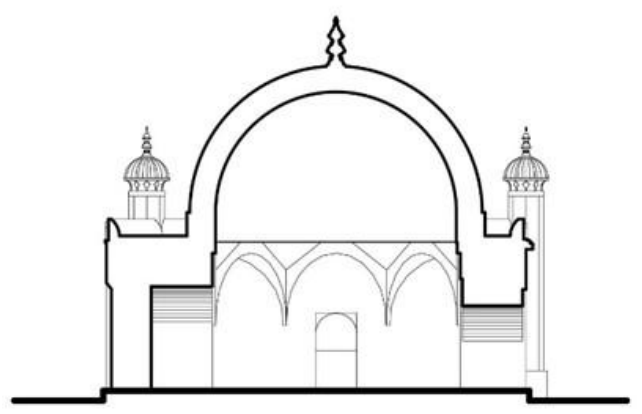

Figure 19: Section through East-West axis (Drawn by authors)

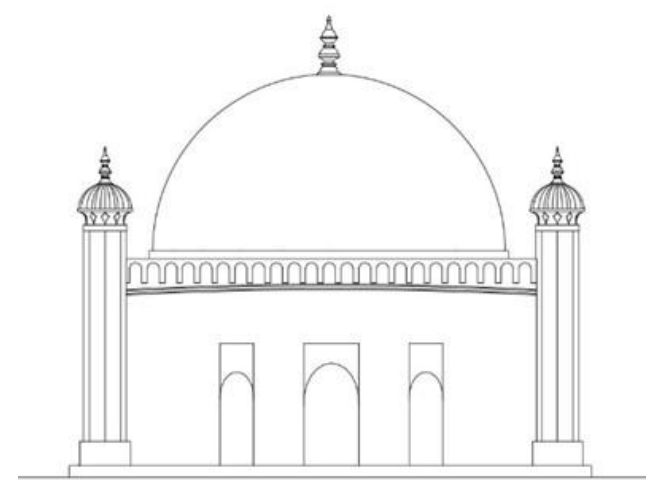

Figure 20: East (Front) Elevation(Drawn by authors)

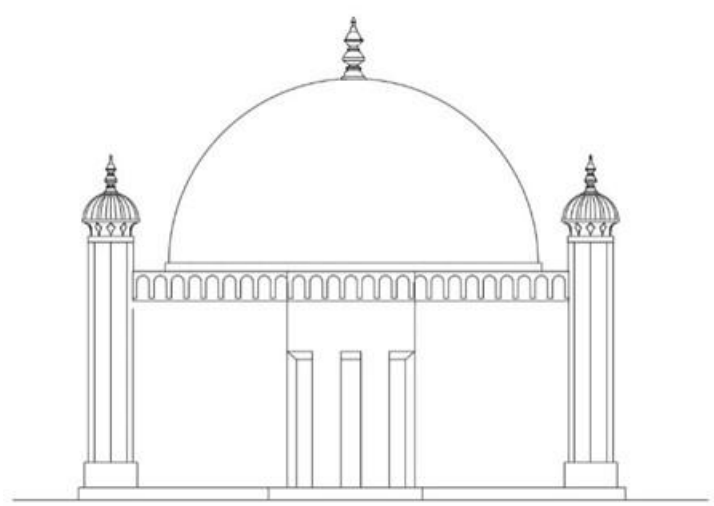

Figure 21: West Elevation (Drawn by authors)

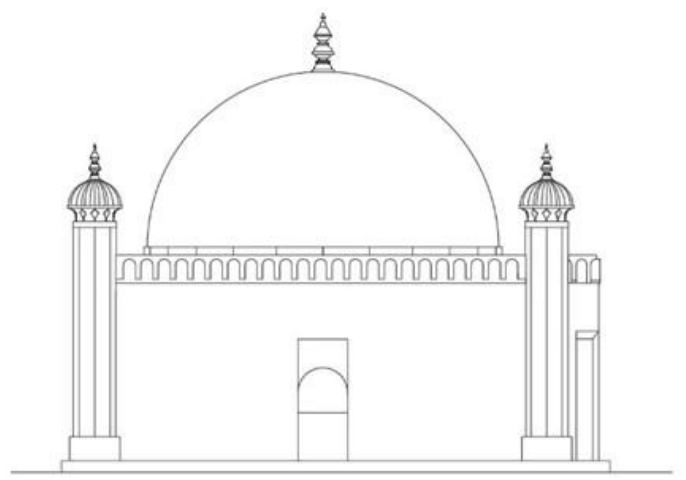

Figure 22: North Elevation (Drawn by authors)

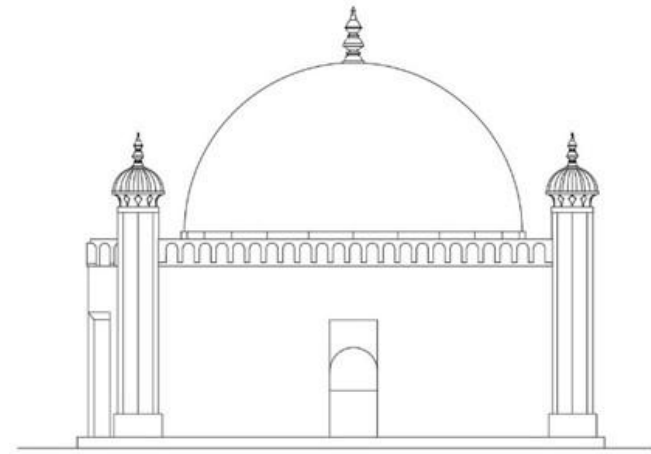

Figure 23: South Elevation (Drawn by authors)

Summary of findings: Phases of physical changes of Gayebi mosque over time (Figure 24-25)

- $\quad$ Based on the conflicting and contradictory architectural evidence, it can be assumed that the original mosque was renovated, restored, or perhaps reconstructed quite a few times over the long years of its existence. So, different features may have been added to the original structure of the mosque during a different time period.

- $\quad$ The exterior walls of the main structure were constructed in the initial phase, which can be assumed as the Sultanate period based on the core architectural feature, which resembles other mosques from the Sultanate era.

- Dome and corner turrets were constructed during the original construction of the mosque, which we have assumed during the Sultanate period.

- The decoration above the corner turrets, cupola, pinnacle over the dome, and the Marlon on the cornice are added during a later period, as these features are not possible to be built during the original construction during Sultanate period. And since these features are an example of Mughal architecture, it can be assumed that they were added at some point during the Mughal period.

- In the past decade, two RCC lintel was constructed to hang ceiling fans, which collide with the architectural feature of this structure as well as the conservation manual of Bangladesh.

- $\quad$ By examining the interior and exterior wall cement- mortar plaster found in several places of the mosque shows the evidence of conservation works done in several phases in the last hundred years. 


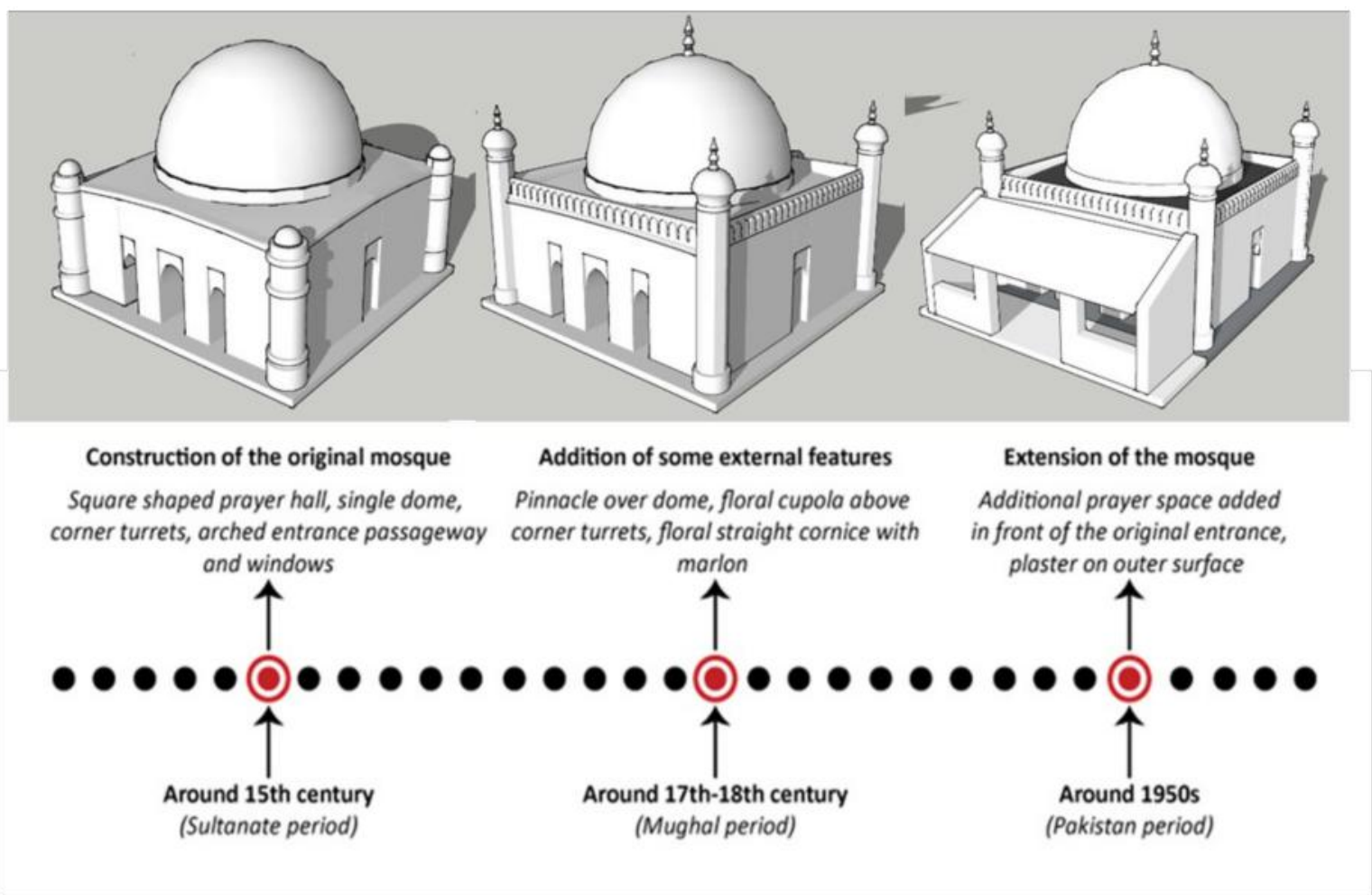

Figure-24: 3D models of predicted phases of Gayebi Mosque changes with the timeline (By authors)

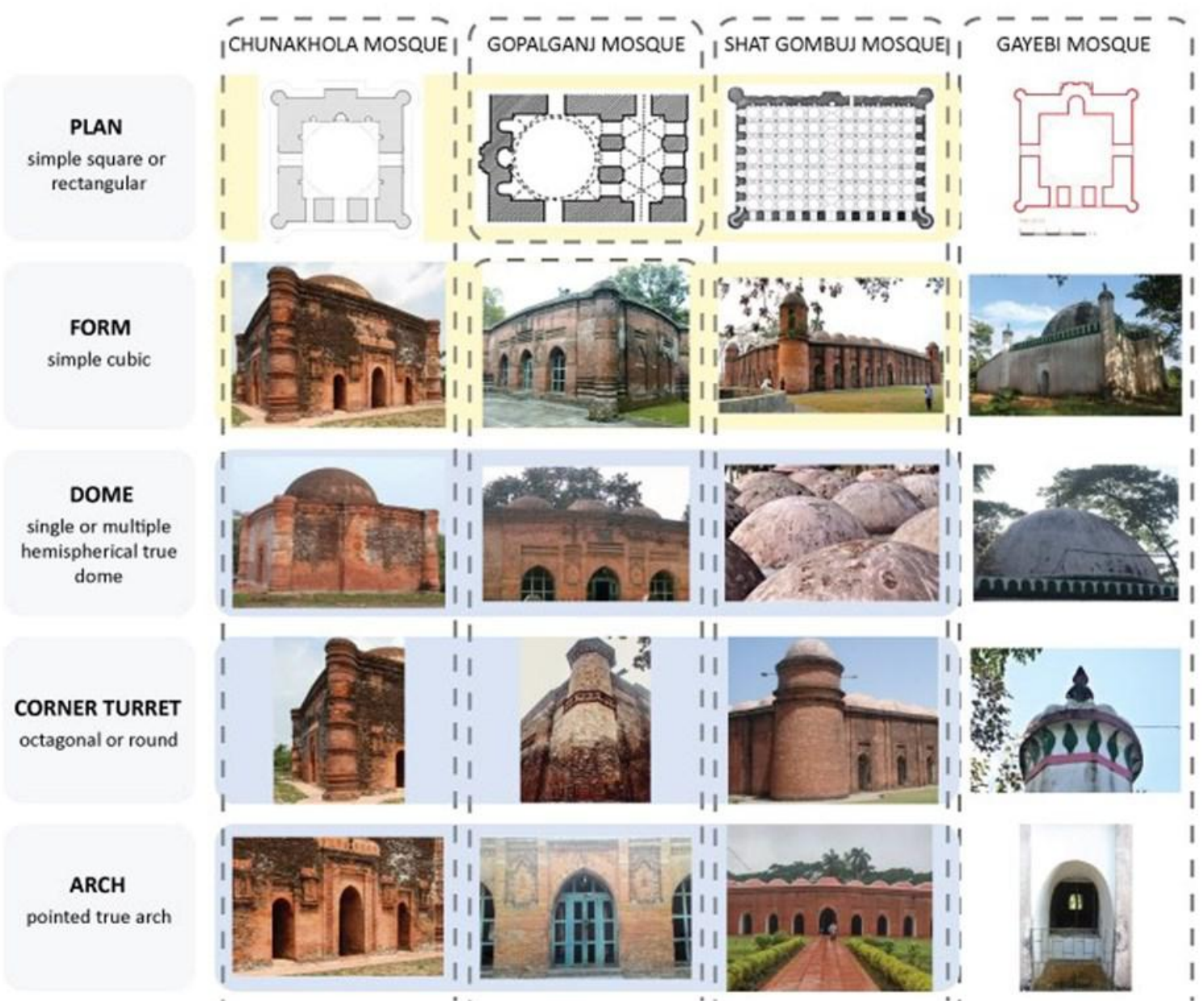




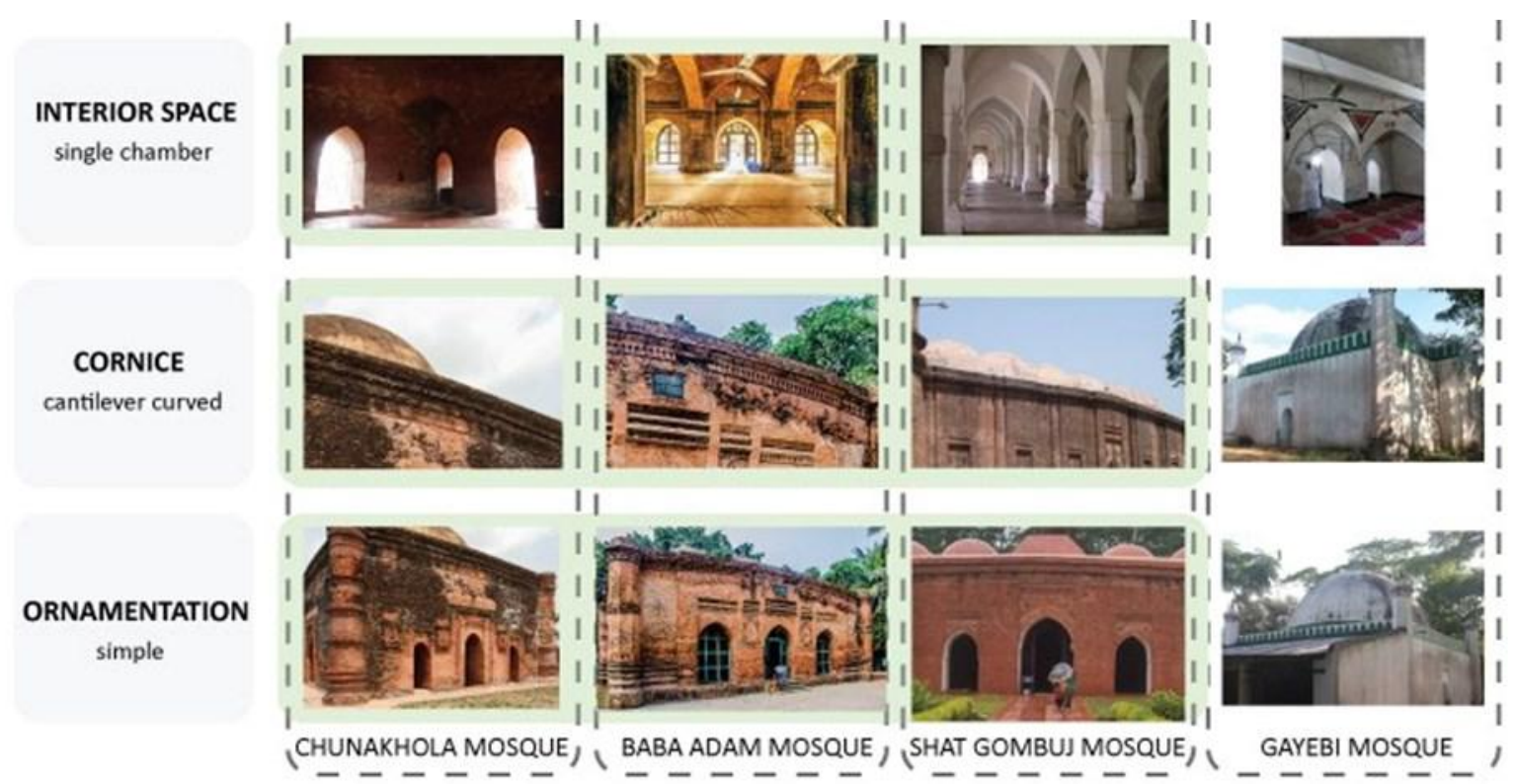

Figure 25: Characteristics of Sultanate Mosque Architecture of Bengal; and its comparison with Gayebi Mosque (Graphic by authors)

\section{CONCLUSION}

Even after the study was finished, we are not completely sure about the origin of the mosque. Still, through careful investigation and examination of the definite evidence, we have come to a logical conclusion regarding the mosque's architectural origin.

Figure 25 shows that the Gayebi mosque has similar architectural features as another sultani mosque of Bangladesh. As we have understood, the mosques of the Sultanate period were more straightforward in the plan, form, and other features, while comparatively, the mosques of the Mughal era were more involved with more additive imperial features. In this regard, based on the study and investigation, The architecture of the Gayebi mosque indicates the original structure of the mosque was probably built during the Sultanate period, while many other external features were added during the later Mughal period as part of renovation or restoration. This juxtaposition of different architectural features indicates the unique legacy of the Gayebi mosque, as it has become a witness of time in the surrounding region through the ages. Further research and study can be conducted on the proper conservation of this significant mosque, which is undoubtedly necessary to preserve its heritage and legacy.

\section{REFERENCES}

[1] M. K. M, The Muslim Heritage of Bengal: The Lives, Thoughts, and Achievements of Great Muslim Scholars, Writers and Reformers of Bangladesh and West Bengal, Markfield: Kube Publishing Limited, 2013.

[2] A. Begum, "Architectural heritage of Sylhet," in Sylhet - History \& Heritage, S.U. Ahmed, Ed.Dhaka, Asiatic Press, 1999, pp. 526-530.
[3] R. Ettinghausen, O. Grabar, and M. Jenkins, Islamic Art and Architecture, New York: Yale University Press, 2003.

[4] A. H. Dani, Muslim Architecture in Bengal, Dacca: Asiatic Society of Pakistan, 1961.

[5] S. M. Hasan, Mosque Architecture of Pre-Mughal Bengal, Dhaka, 1979.

[6] C. B. Asher, "Inventory of key monuments," in The Islamic Heritage of Bengal, G. Michell, Ed. Paris, UNESCO, 1984, pp. 37-140.

[7] N. Ahmed, Discover the Monuments of Bangladesh, Paris: UNESCO, 1984.

[8] Banglapedia, "Banglapedia," Asiatic Society of Bangladesh,2015.[Online].Available:http:// en.banglapedia.org/index.php? title=Chuna_Khola_Mosque. [Accessed 811 2019].

[9] P. Hasan, Sultans, and Mosques: The Early Muslim Architecture of Bangladesh, London: Tauris, 2007.

[10] I. Islam and A. Noble, "Mosque Architecture in Bangladesh: The Archetype and Its Changing Morphology," Journal of Cultural Geography, vol. 17, no. 2, pp. 5-25, 2011.

[11] A. S. M. Ahmed and S. Z. Hossain, Mosque architecture in Bangladesh, Paris: UNESCO, 2006.

[12] M. A. Bari, "Shatgumbad Mosque," in Banglapedia: National Encyclopedia of Bangladesh, Dhaka: Asiatic Society, 2012.

[13] T. Fazal, Minority Nationalisms in South Asia, London: Routledge, 2013.

[14] A. Karim, "Islam in Sylhet \& Hazarat Shahjalal," in Sylhet-History and heritage, S.U. Ahmed, Ed. Dhaka: Bangladesh Itihas Somiti, 1999, p. 103.

[15] N. Titled, "Brief History Of Establishment Of The Upazila And It's Naming," [Online]. 
Investigating The Architectural Origin of The Gayebi Mosque in Osmanpur, Sylhet, Bangladesh

Available: http://bit.ly/2qi8ERx. [Accessed 1111 2019].

[16] A. B. M. Husain, "Medieval Period: The Sultanate Architecture," in Architecture volume, Cultural Survey of Bangladesh Series, A.B.M Husain, Ed. Dhaka: The Asiatic Society of Bangladesh, 2007, p. 100. 